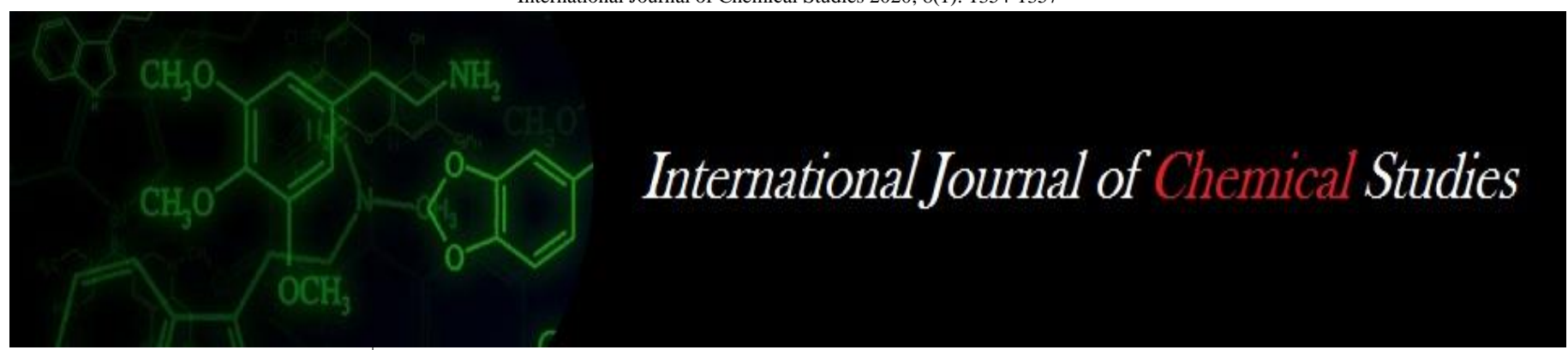

P-ISSN: 2349-8528

E-ISSN: 2321-4902

IJCS 2020; 8(1): 1354-1357

(C) 2020 IJCS

Received: 07-11-2019

Accepted: 09-12-2019

\section{Irfan MM}

Department of Agronomy, College of Agriculture University of Agricultural and Horticultural Sciences, Shivamogga,

Karnataka, India

Veeranna HK

Department of Agronomy, College of Agriculture University of Agricultural and Horticultural Sciences, Shivamogga

Karnataka, India

Girijesh GK

Department of Agronomy,

College of Agriculture University of Agricultural and Horticultural Sciences, Shivamogga,

Karnataka, India

Dinesh Kumar M

Department of Agronomy,

College of Agriculture University of Agricultural and Horticultura

Sciences, Shivamogga,

Karnataka, India

\section{Ganapathi}

Department of Soil Science and Agricultural Chemistry, OFRC

University of Agricultural and

Horticultural Sciences,

Shivamogga, Karnataka, India

Corresponding Author:

Irfan MM

Department of Agronomy,

College of Agriculture University of Agricultural and Horticultural Sciences, Shivamogga,

Karnataka, India

\section{Economics of maize + pole bean intercropping system as influenced by different fertilizer levels in southern transition zone of Karnataka}

\author{
Irfan MM, Veeranna HK, Girijesh GK, Dinesh Kumar M and Ganapathi
}

DOI: https://doi.org/10.22271/chemi.2020.v8.i1s.8441

\begin{abstract}
A field experiment was conducted during Kharif season-2017 and 2018 at Agriculture and Horticultural Research Station, Bavikere. The experiment was laid out in Randomized Complete Block Design with seven treatments and three replication. Maize is grown in paired row of $75 / 45 \mathrm{~cm} \times 30 \mathrm{~cm}$ while pole bean crop was made to grow besides single row of maize in paired row system with $120 \mathrm{~cm} \times 30 \mathrm{~cm}$. Thereby, the whole system had 55,000 and 27,777 population respectively for maize and pole bean. In this system, application 100 per cent RDF of maize (100:50:25 N, P and $\mathrm{K} \mathrm{kg} \mathrm{ha}^{-1}$ ) supplied to both the crops $\left(\mathrm{T}_{1}\right)$ and application 100 per cent RDF of pole bean $\left(63: 100: 75 \mathrm{~N}, \mathrm{P}\right.$ and $\left.\mathrm{K} \mathrm{kg} \mathrm{ha}{ }^{-1}\right)$ supplied to both the component crops $\left(\mathrm{T}_{2}\right)$ were tested against, five different combinations of fertilizer levels (150, $125,100,75,50 \%$ of RDF of both the crops). Among different fertilizer levels tested, application of 150 per cent RDF of maize and pole bean supplied to both the component crops (244.50:225:150 N, P and K $\mathrm{kg} \mathrm{ha}^{-1}$ ) recorded higher grain $\left(75.21 \mathrm{q} \mathrm{ha}^{-1}\right)$, stover $\left(91.88 \mathrm{q} \mathrm{ha}^{-1}\right)$, cumulative pole bean yield (56.81 ha $\left.{ }^{1}\right)$, maize equivalent yield $\left(149.77 \mathrm{q} \mathrm{ha}^{-1}\right)$, gross $\left(₹ 2,60,001 \mathrm{ha}^{-1}\right)$ and net returns $\left(₹ 1,31,285 \mathrm{ha}^{-1}\right)$. Further it was on par with application of 125 and 100 per cent RDF of maize and pole bean supplied to both the crops. However, the plot receiving 100 per cent RDF of maize and pole bean supplied to both the component crops recorded higher B: C (2.46) followed by 125 per cent RDF of maize and pole bean supplied to both the component crops (2.38).
\end{abstract}

Keywords: Maize and pole bean paired row intercropping system, yield and economics

\section{Introduction}

Maize is the second most important cereal crop in the World in terms of acreage and is called the 'Queen of Cereals' because of its highest genetic yield potential among the cereals. By origin, crop is native to South Mexico regarded as the most versatile emerging crop having wider adaptability under varied agro-climatic conditions. In India, it is cultivated in an area of $10.20 \mathrm{~m}$ ha with production of $26.00 \mathrm{~m} \mathrm{t}$ and productivity of $2.60 \mathrm{t} \mathrm{ha}^{-1}$. The maize area in Karnataka has almost doubled during the past one decade and currently it is the largest among all the states in India and also leading producer and exporter with a contribution of about 19 per cent $(4 \mathrm{mt})$ from 15 per cent of maize area $\left(1.33 \mathrm{~m}\right.$ ha) with productivity of $2.90 \mathrm{t} \mathrm{ha}^{-1}$ (Anon., 2018) ${ }^{[1]}$.

Maize crop has wider adaptability and compatibility under diverse soil and climate conditions. Therefore, it is cultivated in sequence or in association with different crops of different growth habit under varied agro ecologies of the country and hence regarded as one of the potential drivers of crop diversification. It is often intercropped with soybean, ground nut, green gram, black gram, cowpea, pigeon pea and field bean etc. Intercropping of maize with legumes such as cowpea, green gram, black gram, and pigeon pea not only improved the productivity and profitability, but the incorporation of legume residues also resulted in saving of about 25 to 30 $\mathrm{kg} \mathrm{N} \mathrm{ha-1}$. In peri urban interface, maize based high value intercropping system involving vegetables are gaining importance owing to market driven farming. Intercropping of high value vegetables with maize provides an additional income depending upon the crop and prevailing market price. Padhi and Panigrahi (2006) ${ }^{[3]}$ opined that intercropping of maize and climbing bean are advisable because the yield of component crops are optimum and achieved higher land equivalent ratio. Maize and pole bean as component crop in an intercropping system which improves the soil condition by reducing the amount of nutrient taken from the 
soil and balances the nutrient for the next season crops. Similarly, Onduru et al. (2007) ${ }^{[2]}$ also indicated that intercropping of maize with beans reduced nutrient decline compared with sole cropping of either of the two crops. The difference in growth duration and morphology made it suitable for an alternative system for small scale farmers to improve their income and food production per unit area of land. Keeping these things in view the present, experiment on "Economics stability of maize + pole bean intercropping system as influenced by different fertilizer levels in Southern Transition Zone of Karnataka” was undertaken.

\section{Material and Methods}

A field experiment was conducted during Kharif season of2017 and 2018 at Agriculture and Horticultural Research station, Bavikere, which is situated in the Southern Transition Zone (Zone-7) of Karnataka. The experimental site is situated at $75^{\circ} 42^{\prime} \mathrm{N}$ latitude and $75^{\circ} 51^{\prime} \mathrm{E}$ longitude with an altitude of $695 \mathrm{~m}$ above mean sea level (MSL). The soil was sandy loam in texture, slightly acidic $\mathrm{pH}$ (6.04) and normal in electrical conductivity $\left(0.27 \mathrm{dS} \mathrm{m}^{-1}\right)$, low organic carbon $4.8 \mathrm{~g}$ $\mathrm{kg}^{-1}$ and medium in available nitrogen (337 kg ha-1), phosphorus (35.37 $\left.\mathrm{kg} \mathrm{ha}^{-1}\right)$ and potassium status $(255.13 \mathrm{~kg}$ $\left.\mathrm{ha}^{-1}\right)$.

Field experiment was laid out in the Randomized Complete Block Design with seven treatments and replication three. Treatments consisted of seven different doses of fertilizer for maize and pole bean $(150,125,100,75,50 \%$ of recommended dose of fertilizer $\mathrm{N}, \mathrm{P}$ and $\mathrm{K}$ ) in maize + pole bean intercropping system. The field was laid out as per plan of layout and the plots were marked. Furrows were opened at $60 \mathrm{~cm}$ apart and one seeds per spot was dibbled at $30 \mathrm{~cm}$ within a row as per the treatment. In paired row configuration at spacing of $75 / 45 \times 30 \mathrm{~cm}$ maize seeds were dibbled in the pairs of furrows opened at the spacing of $45 \mathrm{~cm}$ and the spacing given between pairs was $75 \mathrm{~cm}$. The seeds were dibbled in the rows at the spacing of $30 \mathrm{~cm}$ under both the methods. The pole bean seeds were placed at about $5-8 \mathrm{~cm}$ away to the dibbled maize seed in the same furrow so that pole bean was sown at regular spacing of $120 \mathrm{~cm}$ between rows and $30 \mathrm{~cm}$ between plants. Fertilizers were applied to both main and intercrop as per the treatment details (RDF for maize-100:50:25 and pole bean- 63:100:75 $\mathrm{kg} \mathrm{N}, \mathrm{P}_{2} \mathrm{O}_{5}$ and $\mathrm{K}_{2} \mathrm{O}$ ha $^{-1}$ ). Yield observations, Cost of cultivation, Gross return, Net return and Benefit cost Ratio of the crops were subjected to analysis.

\section{Treatment details}

$\mathrm{T}_{1}: 100 \% \mathrm{RDF}$ of Maize supplied to both the crops (100:50:25 N, P and K kg ha ${ }^{-1}$ )

$\mathrm{T}_{2}: 100 \%$ RDF of Pole bean supplied to both the crops (63:100:75 N, P and K kg ha $\left.{ }^{-1}\right)$

$\mathrm{T}_{3}: 50 \%$ RDF of Maize and Pole bean supplied to both the crops

(81.5:75:50 N, P and $\left.\mathrm{K} \mathrm{kg} \mathrm{ha}^{-1}\right)$

$\mathrm{T}_{4}: 75 \% \mathrm{RDF}$ of Maize and Pole bean supplied to both the crops

(122.25:112.5:75 N, P and $\left.\mathrm{K} \mathrm{kg} \mathrm{ha}^{-1}\right)$

$\mathrm{T}_{5}: 100 \% \mathrm{RDF}$ of Maize and Pole bean supplied to both the crops

$\left(163: 150: 100 \mathrm{~N}, \mathrm{P}\right.$ and $\left.\mathrm{K} \mathrm{kg} \mathrm{ha}{ }^{-1}\right)$

$\mathrm{T}_{6}: 125 \% \mathrm{RDF}$ of Maize and Pole bean supplied to both the crops

(203.75:187.5:125 N, P and $\mathrm{K} \mathrm{kg} \mathrm{ha}^{-1}$ )
$\mathrm{T}_{7}: 150 \%$ RDF of Maize and Pole bean supplied to both the crops (244.50:225:150 N, P and $\mathrm{K} \mathrm{kg} \mathrm{ha}^{-1}$ )

The varieties used were, CP818 a private hybrid of maize, NZ an exotic hybrid of pole bean. All the experimental data on growth parameters and yield were statistically analyzed and critical difference was worked out as described by Gomez and Gomez (1984).

\section{Economic analysis}

Economics for both the experiments was worked with the prevailing costs during the period of experimentation.

\section{Cost of cultivation}

The cost of input that prevailed at the time of their use was considered to work out the cost of cultivation. The cost of cultivation was worked out considering the material input cost like the seed, manure, fertilizer, plant protection chemicals, etc. and labour for all the operations. Treatment wise cost of cultivation was worked out and expressed as ₹. $\mathrm{ha}^{-1}$. The details of cost input and price of output is furnished in Table 5 .

\section{Gross returns}

The prevailing market prices of main and components crops at the time of harvest were obtained from the Agriculture Produce Market Committee, Shivamogga and was used for the calculation of gross returns and expressed in ₹.

\section{Net returns}

The net returns per hectare was calculated by deducting the cost of cultivation from the gross returns and expressed in ₹.

\section{Benefit: cost}

Benefit cost (BC) was worked out by using the following formula.

$$
\mathrm{BCR}=\frac{\text { Gross returns }\left(₹ \mathrm{ha}^{-1}\right)}{\text { Cost of cultiavtion }\left(₹ \mathrm{ha}^{-1}\right)}
$$

\section{Results and Discussion}

\section{Economics as influenced by different fertilizer levels}

Economics is an ultimate criteria for acceptance and wider adoption of any technology. Among different indicators of economic efficiency in any production system, net returns and $\mathrm{B}: \mathrm{C}$ has greater impact on the practical utility and acceptance of the technology by the farmers.

Data pertaining to cost of cultivation, gross and net returns and $\mathrm{B}: \mathrm{C}$ as affected by fertility levels have been given in (Table 3). The details of the cost of cultivation and economics of different treatments have been given in (Table 5), respectively.

Pooled data (Table 3) indicating that, among different levels of fertilizer application to maize + pole bean intercropping system, application of 150 per cent RDF of maize and pole bean supplied to both the crop $\left(\mathrm{T}_{7}\right)$ recorded higher gross (₹.2, $\left.60,001 \mathrm{ha}^{-1}\right)$ and net returns (₹.1,31,285 ha-1) as compared to 100 per cent RDF of maize and pole bean supplied to both the crops $\left(\mathrm{T}_{5}\right)$ which recorded gross (₹ 2,40,649 $\mathrm{ha}^{-1}$ ) and net returns ( $₹ 1,25,945 \mathrm{ha}^{-1}$ ). Further, it was closely followed by 125 per cent RDF of maize and pole bean supplied to both the crops $\left(\mathrm{T}_{6}\right)$ that recorded higher gross ( $\left.₹ 2,52,735 \mathrm{ha}^{-1}\right)$ and net returns ( $₹ 1,30,854 \mathrm{ha}^{-1}$ ). However, the treatment received 100 per cent RDF of maize and pole bean supplied to both the 
crops has recorded higher B:C (2.46) followed by 125 per cent RDF of maize and pole bean supplied to both the crops $\left(\mathrm{T}_{6} ; 2.38\right)$. A perusal of data revealed that lowest net return, gross return and $\mathrm{B}: \mathrm{C}$ recorded with 100 per cent RDF of maize supplied to both the crops $\left(\mathrm{T}_{1}\right)$ and 100 per cent RDF of pole bean supplied to both the crops $\left(\mathrm{T}_{2}\right)$.

Application of different fertilizer levels helps in higher returns viz., gross return, net return and $\mathrm{B}: \mathrm{C}$ during both the years (Table 3). Graded levels of fertilizer given to maize + pole bean intercropping system differed with respect to economics. Among differed levels, 50 and 75 per cent RDF of maize and pole bean supplied to both the crops recorded ₹. 72,841 and 31,644 lesser gross return and lesser net return ₹ 52,352 and ₹ 23,885 compared to 100 per cent RDF of maize and pole bean supplied to both the crops. Further, 125 and 150 per cent RDF of maize and pole bean supplied to both the crops registered ₹ 7,266 and 19,352 higher gross and higher net return ₹ 4, 900 and ₹ 5, 340 over 100 per cent RDF to both the crops.

Even though there was higher cost of cultivation in treatments received 150, 125 and 100 per cent $\mathrm{RDF}$ of maize and pole bean supplied to both the crops, still it has given higher gross and net returns due to significantly higher grain, straw yield and pole bean yield which resulted in higher maize equivalent yield (Table 1 and 2). Further, higher B:C was recorded in 100 per cent RDF of maize and pole bean supplied to both the crops (2.46) as compared to 125 (2.38) and 150 (2.31) per cent RDF of maize and pole bean supplied to both the crops.

Whereas, the lowest gross returns, net returns and $\mathrm{B}: \mathrm{C}$ registered in 100 per cent RDF of maize supplied to both the crops and 100 per cent RDF of pole bean supplied to both the crops was mainly because of its lower grain, straw yield and pole bean yield. In terms of cost benefit the treatment received 100, 125 and 150 per cent RDF of maize and pole bean supplied to both the crops recorded almost similar values which indicate application of 100 per cent RDF to both the crops is economical.

Every farmer desires maximization of income from the farm produce. Intercropping of vegetables in maize improved the gross returns. The consequence of higher gross and net returns was resulted in higher $\mathrm{B}: \mathrm{C}$ as the MEY of component crops in intercropping system was more with the higher yield and prices. It is quite obvious that growing more than one crop simultaneously in a unit area of land with complementary nature gave higher remunerative returns than growing of single crop on the same piece of land. Higher net returns with maize based intercropping systems are reported by Jasbir Singh and Thenua (2014) ${ }^{[4]}$.

A criss cross view of fertilizer cost alone to that of economic return was revealed the following. Based on the totality of yield obtained returns were calculated and compared with only fertilizer costs involved in each treatment (Table 4). Application of 100 per cent RDF of maize and pole bean supplied to both the crops $\left(\mathrm{T}_{5}\right)$ realized 9.00 while 50 and 75 per cent RDF of maize and pole bean supplied to both the crops $\left(\mathrm{T}_{3}\right.$ and $\left.\mathrm{T}_{4}\right)$ enhanced return level to $₹ 12.54$ and $₹$ 10.53 , respectively. Further, increase in levels of fertilizer decreased the returns. The trend remained same for rupee investment on individual crops also, where in maize responded to a higher level per rupee investment than pole bean. While the trend of response for lower quantity application to a higher degree remained unaltered. Application of 100 per cent RDF of maize and pole bean supplied to both the crops recorded ₹ 9.99 and ₹ 8.18, respectively for maize and pole bean.

Table 1: Grain yield, stover yield and harvest index of maize as influenced by different fertilizer levels in maize + pole bean intercropping system.

\begin{tabular}{|c|c|c|c|c|c|c|c|c|c|}
\hline \multirow{2}{*}{ Treatments } & \multicolumn{3}{|c|}{ Grain yield $\left(\mathrm{q}\right.$ ha $\left.^{-1}\right)$} & \multicolumn{3}{|c|}{ Straw yield $\left(q\right.$ ha $\left.^{-1}\right)$} & \multicolumn{3}{|c|}{ Harvest index } \\
\hline & 2017 & 2018 & Pooled & 2017 & 2018 & Pooled. & 2017 & 2018 & Pooled \\
\hline $\mathrm{T}_{1}: 100 \%$ RDF of maize supplied to both the crops $(100: 50: 25)$ & 55.45 & 58.85 & 57.15 & 66.60 & 69.39 & 67.99 & 0.43 & 0.43 & 0.43 \\
\hline $\mathrm{T}_{2}: 100 \%$ RDF of Pole bean supplied to both the crops $(63: 100: 75)$ & 42.72 & 46.27 & 44.50 & 55.62 & 59.15 & 57.38 & 0.43 & 0.42 & 0.43 \\
\hline $\mathrm{T}_{3}: 50 \%$ RDF of maize and pole bean supplied to both the crops $(81.5: 75: 50)$ & 51.67 & 54.71 & 53.19 & 61.86 & 64.70 & 63.28 & 0.43 & 0.42 & 0.43 \\
\hline $\mathrm{T}_{4}: 75 \%$ RDF of maize and pole bean supplied to both the crops (122.25:112.5:75) & 61.15 & 66.73 & 63.94 & 76.40 & 79.97 & 78.19 & 0.42 & 0.45 & 0.44 \\
\hline $\mathrm{T}_{5}: 100 \%$ RDF of maize and pole bean supplied to both the crops $(163: 150: 100)$ & 65.67 & 74.01 & 69.84 & 82.73 & 86.37 & 84.55 & 0.44 & 0.45 & 0.45 \\
\hline $\mathrm{T}_{6}: 125 \%$ RDF of maize and pole bean supplied to both the crops $(203.75: 187.5: 125)$ & 69.62 & 77.39 & 73.51 & 87.31 & 91.05 & 89.18 & 0.44 & 0.46 & 0.45 \\
\hline T7: $150 \%$ RDF of maize and pole bean supplied to both the crops $(244.25: 200: 150)$ & 71.13 & 79.29 & 75.21 & 89.86 & 93.89 & 91.88 & 0.44 & 0.46 & 0.45 \\
\hline S. Em \pm & 1.90 & 2.02 & 1.96 & 2.43 & 2.98 & 2.71 & 0.02 & 0.01 & 0.02 \\
\hline $\mathrm{CD}(\mathrm{P}=0.05)$ & 5.85 & 6.24 & 6.04 & 7.50 & 9.19 & 8.34 & NS & NS & NS \\
\hline
\end{tabular}

Table 2: Yield of pole bean and maize equivalent yield as influenced by different fertilizer levels in maize + pole bean intercropping system.

\begin{tabular}{|c|c|c|c|c|c|c|}
\hline \multirow{2}{*}{ Treatments } & \multicolumn{3}{|c|}{ Cumulative pole bean yield $\left(\mathrm{q} \mathrm{ha}^{-1}\right)$} & \multicolumn{3}{|c|}{ MEY $(\mathbf{q ~ h a - 1})$} \\
\hline & 2017 & 2018 & Pooled & 2017 & 2018 & Pooled \\
\hline $\mathrm{T}_{1}: 100 \%$ RDF of maize supplied to both the crops $(100: 50: 25)$ & 23.12 & 25.65 & 25.37 & 87.90 & 90.91 & 89.41 \\
\hline $\mathrm{T}_{2}: 100 \%$ RDF of Pole bean supplied to both the crops $(63: 100: 75)$ & 33.41 & 36.65 & 36.42 & 89.61 & 92.08 & 90.85 \\
\hline $\mathrm{T}_{3}: 50 \%$ RDF of maize and pole bean supplied to both the crops $(81.5: 75: 50)$ & 31.32 & 33.42 & 33.15 & 95.63 & 96.49 & 96.06 \\
\hline $\mathrm{T}_{4}: 75 \%$ RDF of maize and pole bean supplied to both the crops $(122.25: 112.5: 75)$ & 40.12 & 44.87 & 44.12 & 117.46 & 122.82 & 120.14 \\
\hline $\mathrm{T}_{5}: 100 \%$ RDF of maize and pole bean supplied to both the crops $(163: 150: 100)$ & 48.12 & 55.57 & 52.51 & 133.20 & 143.47 & 138.33 \\
\hline $\mathrm{T}_{6}: 125 \%$ RDF of maize and pole bean supplied to both the crops (203.75:187.5:125) & 51.45 & 57.54 & 54.16 & 141.84 & 149.32 & 145.58 \\
\hline T7: 150\% RDF of maize and pole bean supplied to both the crops $(244.25: 200: 150)$ & 53.52 & 59.19 & 56.81 & 146.25 & 153.28 & 149.77 \\
\hline S. Em \pm & 1.61 & 1.59 & 1.47 & 4.01 & 3.95 & 3.98 \\
\hline $\mathrm{CD}(\mathrm{P}=0.05)$ & 4.96 & 4.89 & 4.54 & 12.37 & 12.16 & 12.27 \\
\hline
\end{tabular}


Table 3: Economics of maize as influenced by different fertilizer levels in maize + pole bean intercropping system.

\begin{tabular}{|c|c|c|c|c|c|c|c|c|c|c|c|c|}
\hline \multirow{2}{*}{ Treatment } & \multicolumn{3}{|c|}{ Cost of cultivation $\left(₹\right.$ ha $^{-1}$ ) } & \multicolumn{3}{|c|}{ Gross returns $\left(₹\right.$ ha $\left.^{-1}\right)$} & \multicolumn{3}{|c|}{ Net returns (₹ ha-1) } & \multicolumn{3}{|c|}{ B:C } \\
\hline & 2017 & 2018 & Pooled & 2017 & 2018 & Pooled & 2017 & 2018 & Pooled & 2017 & 2018 & Pooled \\
\hline $\begin{array}{l}\mathrm{T}_{1}: 100 \% \text { RDF of maize } \\
\text { to both the crops }(100: 50: 25)\end{array}$ & 82795 & 85545 & 84170 & 139894 & 173962 & 156928 & 57099 & 72758 & 64929 & 1.69 & 2.03 & 1.86 \\
\hline $\begin{array}{l}\mathrm{T}_{2}: 100 \% \text { RDF of Pole bean } \\
\text { to both the crops }(63: 100: 75)\end{array}$ & 88074 & 90824 & 89449 & 138820 & 178487 & 158653 & 50746 & 69204 & 59975 & 1.58 & 1.97 & 1.77 \\
\hline $\begin{array}{c}\mathrm{T}_{3}: 50 \% \text { RDF of maize and pole bean } \\
\text { to both the crops }(81.5: 75: 50)\end{array}$ & 84485 & 87235 & 85860 & 149724 & 185892 & 167808 & 65239 & 81948 & 73593 & 1.77 & 2.13 & 1.95 \\
\hline $\begin{array}{l}\mathrm{T}_{4}: 75 \% \text { RDF of maize and pole bean } \\
\text { to both the crops }(122.25: 112.5: 75)\end{array}$ & 93187 & 95937 & 94562 & 182864 & 235146 & 209005 & 89677 & 114443 & 102060 & 1.96 & 2.45 & 2.21 \\
\hline $\begin{array}{l}T_{5}: 100 \% \text { RDF of maize and pole bean } \\
\text { to both the crops }(163: 150: 100)\end{array}$ & 97539 & 98289 & 97914 & 206694 & 274605 & 240649 & 109155 & 142735 & 125945 & 2.12 & 2.79 & 2.46 \\
\hline $\begin{array}{l}\mathrm{T}_{6}: 125 \% \text { RDF of maize and pole bean } \\
\text { to both the crops }(203.75: 187.5: 125)\end{array}$ & 104617 & 107367 & 105992 & 219583 & 285888 & 252735 & 114966 & 146743 & 130854 & 2.10 & 2.66 & 2.38 \\
\hline $\begin{array}{l}\mathrm{T}_{7}: 150 \% \text { RDF of maize and pole bean } \\
\text { to both the crops }(244.25: 200: 150)\end{array}$ & 111394 & 113444 & 112419 & 226382 & 293620 & 260001 & 114988 & 147582 & 131285 & 2.03 & 2.59 & 2.31 \\
\hline
\end{tabular}

Table: 4: Analysis of economic return and total fertilizer cost in maize + pole bean intercropping system.

\begin{tabular}{|c|c|c|c|c|c|c|c|c|c|}
\hline Treatment & \begin{tabular}{|c|} 
Maize \\
fertilizer \\
cost ₹ \\
\end{tabular} & $\begin{array}{c}\text { Pole bean } \\
\text { fertilizer } \\
\text { cost } ₹\end{array}$ & \begin{tabular}{|c|} 
Total \\
Fertilizer \\
Cost ₹ \\
\end{tabular} & $\begin{array}{c}\text { Maize } \\
\text { Return } \\
₹\end{array}$ & $\begin{array}{c}\text { Pole bean } \\
\text { Return } \\
₹\end{array}$ & $\begin{array}{c}\text { Total } \\
\text { Return } \\
₹\end{array}$ & $\begin{array}{c}\text { Ratio of total returns } \\
\text { To fertilizer cost } \\
₹\end{array}$ & $\begin{array}{c}\text { Ratio of maize return } \\
\text { To fertilizer cost } \\
₹\end{array}$ & $\begin{array}{c}\text { Ratio of pole bean return } \\
\text { To fertilizer cost } \\
₹ \\
\end{array}$ \\
\hline & $\mathbf{A}$ & B & $\mathrm{C}=\mathrm{A}+\mathrm{B}$ & D & $\mathbf{E}$ & $F=D+E$ & $\mathbf{G}=\mathbf{F} / \mathbf{C}$ & H=D/A & $\mathrm{I}=\mathrm{E} / \mathrm{B}$ \\
\hline $\mathrm{T}_{1}:$ & 10565 & - & 10565 & 86411 & 50740 & 137151 & 12.98 & 8.17 & - \\
\hline $\mathrm{T}_{2}:$ & - & 12844 & 12844 & 67276 & 72840 & 140116 & 10.91 & - & 5.67 \\
\hline$T_{3}:$ & 5283 & 6422 & 11705 & 80423 & 66300 & 146723 & 12.54 & 15.22 & 10.32 \\
\hline $\mathrm{T}_{4}:$ & 7924 & 9633 & 17557 & 96678 & 88240 & 184918 & 10.53 & 12.2 & 9.16 \\
\hline $\mathrm{T}_{5}:$ & 10565 & 12844 & 23409 & 105592 & 105022 & 210614 & 9.00 & 9.99 & 8.18 \\
\hline $\mathrm{T}_{6:}$ & 13206 & 16055 & 29262 & 111143 & 108327 & 219470 & 7.50 & 8.42 & 6.75 \\
\hline $\mathrm{T}_{7}:$ & 15848 & 19266 & 35114 & 113722 & 113612 & 227333 & 6.47 & 7.18 & 5.90 \\
\hline
\end{tabular}

Table: 5 Prices of inputs and outputs

\begin{tabular}{|c|c|c|}
\hline Sl. No. & Particulars & Price (₹) \\
\hline \multicolumn{3}{|c|}{ Seed material } \\
\hline 1 & Maize & $190 \mathrm{~kg}^{-1}$ \\
\hline 2 & Pole bean & $1600 \mathrm{~kg}^{-1}$ \\
\hline \multicolumn{3}{|c|}{ Chemical fertilisers } \\
\hline 1 & Urea & $6 \mathrm{~kg}^{-1}$ \\
\hline 2 & DAP & $25.6 \mathrm{~kg}^{-1}$ \\
\hline 3 & MOP & $16.80 \mathrm{~kg}^{-1}$ \\
\hline 4 & ZnSO & $40 \mathrm{~kg}^{-1}$ \\
\hline 5 & FYM & $600 \mathrm{t}^{-1}$ \\
\hline \multicolumn{3}{|c|}{ Labour wages } \\
\hline 1 & Men & $300 \mathrm{day}^{-1}$ \\
\hline 2 & Women & $250 \mathrm{day}^{-1}$ \\
\hline 3 & Tractor rent \\
\hline \multicolumn{3}{|c|}{ Output } \\
\hline 1 & Maize grain \\
\hline 2 & Pole bean fresh green pods & $1450 \mathrm{hr}^{-1}$ \\
\hline \multicolumn{3}{|c|}{} \\
\hline
\end{tabular}

\section{Conclusion}

Application of different fertilizer levels, application of 150 per cent RDF of maize and pole bean supplied to both the component crops $\left(244.50: 225: 150 \mathrm{~N}, \mathrm{P}\right.$ and $\left.\mathrm{K} \mathrm{kg} \mathrm{ha}{ }^{-1}\right)$ recorded gross (₹ 2, 60,001 ha-1) and net returns (₹ 1, 31,285 $\left.\mathrm{ha}^{-1}\right)$. Further it was on par with application of 125 and 100 per cent RDF of maize and pole bean supplied to both the crops. However, the plot receiving 100 per cent RDF of maize and pole bean supplied to both the component crops recorded higher B:C (2.46) followed by application 125 per cent RDF of maize and pole bean supplied to both the component crops (2.38).

\section{References}

1. Anonymous, Area, production and productivity of major cereals in India, 2018.

Http//Www.Indiastat.Com
2. Onduru Davies P, Chris. Spatial and Temporal Aspects of Agricultural Sustainability in the semi-arid tropics: a case study in Mbeere District, eastern Kenya. Trop. Sci. 2007; 47:134-148.

3. Padhi AK, Panigrahi RK. Effect of Intercrop and Crop Geometry on Productivity, Economics, Energetics and Soil-Fertility Status of Maize (Zea mays)-Based Intercropping Systems. 2006; 51:174-177.

4. Singh J, Thenua OVS. Growth and yield of Soybean as Influenced by Maize + Soybean Intercropping Systems and nitrogen levels. Ann. Agric. Res. New Series. 2014; 35(1):32-36. 